\title{
Land Tenure Security and Health Nexus: A Conceptual Framework for Navigating the Connections between Land Tenure Security and Health
}

\author{
Walter Dachaga * (D) and Walter Timo de Vries (D)
}

check for updates

Citation: Dachaga, W.; de Vries, W.T. Land Tenure Security and Health Nexus: A Conceptual Framework for Navigating the Connections between Land Tenure Security and Health. Land 2021, 10, 257. https://doi.org/ $10.3390 /$ land 10030257

Academic Editor: Liz Alden Wily

Received: 11 February 2021

Accepted: 28 February 2021

Published: 3 March 2021

Publisher's Note: MDPI stays neutral with regard to jurisdictional claims in published maps and institutional affiliations.

Copyright: (c) 2021 by the authors. Licensee MDPI, Basel, Switzerland. This article is an open access article distributed under the terms and conditions of the Creative Commons Attribution (CC BY) license (https:/ / creativecommons.org/licenses/by/ $4.0 /)$.
Chair of Land Management, Department of Aerospace and Geodesy, Technical University of Munich (TUM), 80333 Munich, Germany; wt.de-vries@tum.de

* Correspondence: walter.dachaga@tum.de

\begin{abstract}
The rise of urban populations has rendered cities in both developed and developing countries vulnerable to poor health and diseases that are associated with urban living conditions and environments. Therefore, there is a growing consensus that while personal factors are critical in determining health, the urban environment exacerbates or mitigates health outcomes, and as such the solution for improving health outcomes in urban settings can be found in addressing socioenvironmental factors that shape urban environments. Land tenure security is a social environmental factor of health that has been understudied by urban geographers despite its obvious role in shaping urban environments, housing conditions, and health. We interpret literature and infer possible pathways through which land tenure security connects to health and propose a land tenure security and health nexus conceptual framework for modeling and investigating the extent of this connection. Based on a narrative review of literature, this inter-disciplinary paper shows that land tenure security can influence health outcomes via four pathways-infrastructure access, environmental justice, psycho-ontological security, and social cohesion. Going forward, a subsequent investigation can focus on developing an index of land tenure security health insults, based on which an empirical investigation of the relationship between land tenure security and health disease is possible.
\end{abstract}

Keywords: tenure security; health; urban health; land tenure; urban planning; social determinants; land tenure security and health nexus; environmental justice; land use; land management

\section{Introduction}

City life is a reality for many and is rapidly becoming so for most of the world's population [1-3]. The world today is experiencing a fast pace of urbanization with nearly $70 \%$ of the global population projected to live in urban areas by 2050 [4]. Conventionally, urbanization has been linked to development, and development with health, but in the face of development is the growth of slums, which are characterized by poor health [5]. Cities are therefore characterized by three processes, namely the movement of people into urban centers, development of informal settlements due to lack of tenure, and emergence of environmental and health problems. Thus, while urbanism is idealized to entail social improvements with consequential better quality-of-life for urban residents, on the contrary, in many low-income and some middle-income countries, urbanization conveys inequality and exclusion. This creates cities and dwellings characterized by poverty, overcrowding, poor housing, severe pollution, absence of basic services, and poor health which is defined by the unequal social context that surrounds the daily life of the disadvantaged, and often, socially excluded groups [6]. The rise of urban populations has rendered cities in both developed and developing countries vulnerable to poor health and diseases that are associated with urban living conditions and environments [3]. In response, there is a wealth of literature that recognizes the need to understand the impacts of urban environments and living conditions on the health of urban populations [5,7-13]. There is 
now a growing consensus that while personal factors are critical in determining health, the urban environment exacerbates or mitigates health and well-being outcomes [14,15]. This is because cities are so ubiquitous and their impact so pervasive that it is difficult to consider any aspect of health ignoring urban settings [16]. To emphasize this, Corburn [17] posits that if the global community is serious about the Sustainable Development Goals (SDGs), greater attention must be paid to understanding and acting to improve urban places, living conditions, and the social and economic conditions that can promote health equity. Hence, the solution for improving health outcomes in urban settings lies in addressing urban environments and associated land-people relations than narrowly focusing on healthcare systems-a stance aligned with socio-environmental determinants of global health [18].

The literature on addressing urban environments to promote health connections is diverse but distributed in professional silos. Most of the literature has subscribed to a planning approach and either praised or blamed urban planning approaches or their absence for the health conditions in urban areas or advocated urban planning as a solution to urban health conditions [13,19-21]. Many have attributed urban health conditions to urban green spaces [22-26], urban density [27,28], transport planning [29,30], environmental pollution including air, water, and noise pollution [31-33], urban land use changes [34-36], and lack of basic infrastructure and water and sanitation facilities [12]. For many, the picture that comes to mind at the mention of urban health is the striking informal settlement that comes with urbanization in most developing countries. The mention of informal settlements creates a picture of poor health and high disease burden and informality which is identified with lack of space and tenure insecurity $[13,37,38]$.

People to land relations and land tenure security are central to the informality, high disease burden, environmental pollution, density, blue-green spaces, land use change, sanitation, and basic infrastructure which are identified with health in urban areas. Land tenure security provides rights that enable access to blue-green spaces, urban infrastructure, and services, while also providing the incentive for environmental stewardship and investment in household infrastructure such as water and sanitation facilities to improve living conditions. Yet, urban planning literature $[13,19,21]$ has made implicit the complex role of land tenure and tenure security in understanding urban environments and health. Some scholars $[13,20]$, in advancing an urban planning course, have argued in the wake of recent pandemics that urban planning, a profession that emerged in the late nineteenth century with a goal of improving the health of the least well-off urban residents, has lost its focus throughout the twentieth century. However, we think that urban planning has not necessarily lost focus, rather it has failed to explicitly leverage the role of land tenure security in urban planning to unleash the full health benefits. While the urban planning and health nexus articulated in literature cannot be underestimated [13], we argue that underlying planning is land tenure which, when combined with planning, leads to improvement in livelihoods [39], quality of life [40] and health. Therefore, focusing on urban planning as a solution to urban health conditions without tenure is a recipe for gentrification [41], which in itself has implications on health [42-44]. Planning and land tenure have land use in common, and while planning organizes space according to uses, tenure connects people to these organized spaces. Therefore focusing on planning alone leads to "urban planning dilemma", where those with legitimate rights to land are different from those deciding how and what to use the land for [45] - a situation which has implications for urban environmental outcomes and health.

Land tenure security is a socio-environmental factor of health that is hardly referenced in the debates about urban built environments and health connections. Nevertheless, it plays an obvious role in shaping urban environments, housing conditions, and for that matter health. Made explicit, Watson [46] emphasizes the importance of land tenure and health in the following excerpt:

"Our identity as human beings remains tied to our land, to our cultural practices, our systems of authority and social control, our intellectual traditions, our concepts of spiritu- 
ality, and to our systems of resource ownership and exchange. Destroy this relationship and you damage — sometimes irrevocably—individual human beings and their health."

Although this quote clearly recognizes that land tenure is a determinant of health and well-being, the pathway for such association is multi-directional [46] and less understood. In fact, it still sits at the heart of much academic and policy debates which promote tenure choices to deliver certain outcomes including sustainable cities and housing, green cities, clean cities, land degradation neutrality, environmental conservation, and various SDGs $[4,38,47-49]$. A growing land tenure insecurity correlates with a growing poverty level and volume. A growing poverty level and volume correlates with an increase in compromising of health issues. An increase of compromising of health issues increases the amount of disadvantaged urban population. Yet, it remains unclear how, where, when, through which mechanisms, and under which conditions land tenure insecurity drives and affects health issues. A fundamental issue in land management literature is that there is little reference to health. Likewise, health literature hardly refers to land tenure or land tenure security. In effect, there are insufficient provisions for health in the formulation of land policies and insufficient provisions of land tenure in health policy formulation. Hence, health issues are never a comprehensive part of land policy formulation or are the immediate objectives of land tenure security interventions. Consequently, there are no explicit formal connections between land tenure security and health, which is an omission in both science, policy, and practice. There is no comprehensive study that connects land tenure security with health despite several studies which suggest potential linkages between the two variables [49-54]. The ones that have attempted this connection $[47,50,51,55,56]$ have either ended up alleging a link between land tenure security and health without showing the mechanisms and pathways of this link [51], are not grounded on theoretical and conceptual frameworks [50], or based on a limited scope of what constitutes tenure [47].

This study fills this gap by a process of inferring from existing documentation what the connections between land tenure security and health could be and how this could translate into a land tenure security and health nexus conceptual framework. Such a framework would make the pathways through which variations in land tenure security on the one hand and health issues on the other hand influence or affect each other. The objective of this inference review is to derive the scope, extent, nature, and gaps of existing research on urban environments and health from a land tenure lens/perspective, to identify the pathways through which land tenure security and health are linked, and to develop a land tenure security and health nexus conceptual framework for understanding these linkages. The study sets the stage for further investigation for measuring and empirically investigating the relationship between land tenure security and health outcomes and diseases.

In the next section, we demystify the concepts of health, tenure security, and theoretical foundations of the land tenure security and health nexus. Section 3 describes the methods used in this review. In Section 4, we synthesize findings on the land tenure security and health nexus highlighting the existing evidence of the potential linkages between land tenure security and health. We then present, in Section 5, the land tenure security and health nexus conceptual framework and conclude with implications and recommendations for further research.

\section{Land Tenure Security and Social Determinants of Health: Theoretical Framing}

Ansari et al. [57] argue that there is a need for (inter-disciplinary) theoretical frameworks that encompass the role of social and environmental determinants of health while acknowledging the crucial inter-connectedness of social context, behavior, and biology. Subsequently, theoretical models such as that by Barton [15] emphasize this need by showing the determinants of health in urban settlements which go beyond the individual to encompass social context in which people live. Although theory by itself is not a panacea, it can help to select key goals and measurable indicators needed to formulate health policies [58]. The strong correlation between proximate determinants of health often obscures the impact of distal social factors, including land tenure security, that can 
influence the causal pathways for health outcomes within populations. Therefore, theories guide the selection of key constructs and concepts thought to have influence on health and to explain the multiple social and biological processes that result in embodiment and consequent manifestation in the disease burden and health outcomes of populations and individuals. This new thinking conforms to the ideals of modern social epidemiology-a branch of epidemiology concerned with the way that social experiences, social structures, institutions, and relationships influence health [59]. Current dimensions of health call for integrative and cross-disciplinary research strategies or systems, each directed towards some aspects (including land tenure security) of the complex relationship of health and diseases to society and the individuals [57]. Theories underpin such research and provides the basis for explaining the connections between specified phenomena within and across specified domains by using interrelated sets of ideas whose plausibility can be tested by human action and thought [60]. Before delving into what theory is relevant for advancing the cause of land tenure security and health, it is important to understand what the two concepts denote.

\subsection{Demystifying the Concepts of Land Tenure Security and Health}

Like many concepts, the concepts of land tenure security and health are fluid and, as expected in intellectual discourse, connote different meanings to different individuals and groups, including that it is referred to as housing tenure in some jurisdictions. While the semantics of the concept may be argued differently, we hold the view that land tenure security encompasses housing tenure security. Thus, variants of housing including mortgage, ownership, or rental housing as classified in some jurisdictions, are variants of tenure that come with varying levels of tenure security. Our use of land tenure security is to underscore the fact that land is the basic building block of housing and as such land tenure security and housing tenure security cannot be separated. Particularly in developing country context where real estate markets are dominated by private housing development, tenure in relation to land is mostly precedent to housing tenure. Notwithstanding varying conceptualizations of land tenure [61-66], it fundamentally denotes a rights-based social relationship, whether legal or illegal, between people, land, and society and the basis upon which land is held, used, or owned. The concept of tenure security has evolved in response to efforts to clarify investment incentives of property holders [67]. Varying views on the concept of land tenure security has led to its definition from two broad schools of thought- the assurance and the substance of rights school of thoughts. On the one hand, proponents of the assurance school of thought define security of tenure in terms of the uncertainty of rights, the probability of loss of all or part of the rights held, the expected time of residence before eviction, the uncertainty of changes in government policy, and the impacts of changes in policy on tenure attributes $[62,64,68-71]$. On the other hand, the substance of right school of thought defines land tenure security in terms of the duration of rights, legal title to land, renewability of rights, and the right to sell or transfer land [72,73]. This study shares the views of Bruce and Migot-Adholia [74] that land tenure security exists when an individual perceives that he or she has legitimate claims to a piece of land on a continuous basis, free from imposition or interference from outside sources, as well as the ability to reap the benefits of labor and capital invested in that land, either in use or upon transfer to another holder. Thus, land tenure security exists when one's land tenure is legally recognized through formal registration or documentation; socially recognized through informal, customary, and undocumented tenure arrangements; and/or symbolically recognized through anti-eviction, adverse possession, social legitimacy, and extra-legal means, as well as when such tenure is also perceived to be secure by the tenure rights holder. We acknowledge that tenure is socially constructed and that there are different lenses for looking at land tenure - either via the lens of degree of formality (continuum of land rights) or legality (legal titles to land) both of which confer varying social obligations of land ownership and use-rights, restrictions, and responsibilities. A focus on legality often excludes legitimate and intermediary tenures that proffer enough 
security of tenure that are commensurate with people's circumstances of life. We hold the view that the legality of tenure by way of titles is not necessarily a precondition for land tenure security [75]. Instead, the individual's perception anchored on the degree of formality of tenure and the rights, restrictions, and responsibilities conferred by this formality, is the defining feature of land tenure security. The argument here is not that titles do not guarantee secure tenure, rather that there are multiple ways to achieving land tenure security that is not exclusive to land titles. Hence, we view land tenure security from a degree of formality perspective that enable us to capture the variants of tenure on the tenure continuum including but not limited to private rent, public rent, freehold, co-housing, and squatting.

The concept of health includes the traditional biomedical, ecological, holistic, and other universal concepts [16]. From the traditional point of view, health is the absence of disease and illness. That is a person is healthy if only all organs of the person are functioning normally [16]. From an ecological perspective, health is a relative concept that is influenced by the individual's quality of life and surroundings and depends on the individual's ability to adapt to a dynamic environment and society. Thus, health according to the ecological school of thought is the state of equilibrium between human beings and their environment. The holistic concept of health combines the traditional and ecological concepts by conceptualizing health as multi-dimensional concept that seeks to understand human health within the context of environment, which encompasses the physical and social environment.

Adopting a holistic approach to health, the World Health Organization (WHO) in 1986 defined health as "a state of complete physical, mental, and social well-being and not merely the absence of disease or infirmity". Critics $[16,76,77]$ argue that WHO's definition of health lack specificity in defining well-being, for equating well-being to health, and for assuming health as a perfect state of being, which is practically not achievable. However, the various viewpoints of health articulated by the critics agree that the concept of health is multidimensional, involves the absence of disease, and is not influenced by a single criterion. Therefore, this study subscribes to the WHO's definition of health and multidimensionality of health, based on which the study envisions four dimensions of health-environmental, physical, social, and psychological, which can potentially be affected by land tenure security. The abstract question then is, what has a social science construct such as land tenure security got to do with a biomedical construct of health? A premise for answering this question is identifying a framework that allows for identifying and connecting the two interdisciplinary concepts.

\subsection{Framing Land Tenure Security as a Social Determinant of Health}

Although vigorously speculated in intellectual and policy discourses, land tenure security and health are two distinct concepts that are hardly investigated together. There is literature evidence that hints at linkages between land tenure security and health [50-53,78,79]. The connections between land tenure security and health are mostly investigated without mono-disciplinary theoretical and conceptual frameworks for testing the associations or causal pathways that link land tenure security to health outcomes. On one hand, there are health frameworks $[80,81]$ that link health outcomes with environmental factors, but land tenure security is hardly one of such factors that are linked to health outcomes. On the other hand, there are land management frameworks including sustainable land management framework [82,83], responsible and smart land management framework [84], land governance assessment framework [85], land tenure security and spatial justice framework [86], and tenure responsive land use planning [87] which address land and land tenure security issues but rarely include health matters. Evidence from preliminary reviews of land tenure, urban and environmental health literature, and daily urban life and urbanization experiences suggests that there must be an inter-relation between land tenure security and health diseases. The manifestation of this inter-relation is that land tenure patterns dictate housing patterns and neighborhood conditions which directly affect health outcomes. Similarly, 
land management interventions such as slum upgrades, resettlement, and tenure formalization have delivered improved health and well-being as outcomes through improved tenure, housing, and environmental conditions [56]. Therefore, if land tenure influences housing and environmental conditions and housing and environmental conditions influence health outcomes, there must be a relation between land tenure security and health outcomes. In fact, this relationship exists and manifests in urban informal settlements, but has been given little attention, which has led to some implications on the health burden of urban areas. This makes it compelling to revisit this relationship. However, an understanding of this relation requires an inter-disciplinary integration of theories that combine society, environments, and health. One domain that presents an opportunity for such integration is social production of health and disease theories which combines ecology, biology, and social context to understand distal social and environmental determinants of health.

Three social epidemiology theories which are relevant for understanding health outcomes and socio-environmental context are psychosocial theory, social production of disease theory, and eco-social theory [18]. The three theories agree that health outcomes are results of an interplay between society and biology but differ in their respective emphasis on different aspects of social and biological conditions and how they integrate to shape population health and disease patterns.

The psychosocial theory hypothesizes that the social environment changes host susceptibility by affecting neuroendocrine function [88,89]. It emphasizes endogenous biological responses to human interactions by focusing on responses to stress and on stressed people in need of psychosocial resources but ignores who and what generates psychosocial insults and buffers as well as how their distribution is shaped by social, political, and economic policies [60]. In relation to this study, the theory offers insights for investigating the social and psychological stresses imposed on people by the presence or absence of land tenure security, and the consequences on health outcomes.

The social production of disease theory [90] posits that economic and political institutions and decisions that facilitate economic and social privilege and inequality are the "fundamental causes of inequalities" in health [91]. It focuses on the health impacts of state policies but offers few principles for identifying and investigating what the actual social determinants of health are [60]. Hence, the theory resonates with policy thinking, and in the case of this study, how land and tenure policy set broad social contexts that influence health outcomes.

The eco-social theory embraces the social production of disease approach while engaging a comparable analysis of biology and ecology [60]. The eco-social theory of disease distribution seeks to answer the principal question-what is responsible for population patterns of health, disease, and well-being, as manifested in the present, past, and changing social inequalities in health? [60]. It integrates social and biologic reasoning along with a dynamic, historical, and ecologic perspective to develop new insights into determinants of population distributions of disease and inequalities in health [92]. The key construct of the eco-social theory is embodiment-how humans biologically incorporate the material and social world in which we live, from conception to death.

Two propositions of the eco-social theory are key for relating land tenure and tenure security to health outcomes:

1. Societies' epidemiological profiles are shaped by ways of living which are created by current and changing societal arrangements of power, property, and the production and reproduction of both social and biological life, involving people, other species, and the biophysical world in which we live.

2. In societies exhibiting social divisions based on property and power, and in which those with the most power and resources constitute a small percentage of the population, the more prevalent the health outcome, the greater the absolute burden (and potentially the relative burden) on those with less power and fewer resources, because they constitute the majority of the population. 
In the context of this study, these propositions are relevant for understanding the role of land tenure in health, particularly how variations of land tenure security stratify society, impose differential access to resources, rights, and power that shape health burdens and outcomes of populations and individuals.

Together, the three theories above emphasize the concept of "social position" which underscores social determinants of health [18]. Within this purview, we framed land tenure (security) as a social position, which shapes people's living conditions and health outcomes. In other words, viewed as a social determinant of health, land tenure creates a social structure or relations in society; variations in the nature of tenure and security of tenure create social stratification and assigns individuals to different social positions and circumstances that affect their health.

\section{Materials and Methods}

\subsection{Study Design}

Methodologically, this study adopted a narrative review approach [93]. Narrative reviews are less discriminatory in the identification, assessment, and inclusion of studies, which allows for pooling ideas and evidence from studies of varying scientific quality [94]. Unlike systematic reviews, a narrative approach enables searching more broadly across disciplines [95], which allowed us to search interdisciplinary trends in land tenure, urban health, environmental management, urban planning, land management, and health issues. In addition, new topics such as that under consideration in this study do not have enough primary research data upon which to base conclusions, which makes a narrative review appropriate for approaching both scientific and gray literature to derive new knowledge. Admitting that narrative reviews suffer the criticism of potential bias in literature selection, such bias is not spared in an individual-conducted systematic review. Hence, given the relatively new nature of this study, its interdisciplinarity, and the breadth of related literature across disciplines, we find a narrative review approach more appropriate for this study. Therefore, following Green et al.'s [93] methodological framework for writing narrative reviews, we conducted a narrative review of urban planning, health, and land tenure literature to understand the role of land tenure security in health outcomes. According to Green et al. [93], a narrative review comprises four stages-identification of sources of information, setting parameters and delimiting search terms, defining selection criteria, and summary and synthesis of results.

\subsection{Identification of Sources}

According to Green et al. [93], this stage comprises searching electronic databases, references of known articles and authoritative texts, including expert recommendations and unpublished research. Here, we conducted a search in PubMed, a major public health database, and Web of Science, an interdisciplinary research database. We also handsearched expert recommended scientific and gray literature in Google and Google Scholar which could elude our search parameters due to different indexing in research databases. The inclusion of gray literature was necessary, as research on land tenure security and health linkages are scanty and mostly talked about in policy briefs and organizational reports such as the World Health Organization, UN-Habitat, and Global Land Outlook.

\subsection{Setting of Search Parameters and Terms}

Setting search terms and parameters is required to set comprehensive boundaries that make it possible for the authors to retrieve all relevant studies, while focusing the effort as it is not feasible and practicable to review every single study that has some relation to the topic of interest. Therefore, we conducted a systematic search in PubMed, Web of Science, Google Scholar, and Google in October 2019 (and updated in November 2020) using specific combinations of keywords and terms related to land tenure security, urban health, health, land use, built environment, and urban planning. Due to paucity of literature on the topic, the search was not limited geographically and temporally. However, there was a preference 
for more studies which were relatively recent ( $<10$ years old) without compromising foundational ideas, facts, and logical arguments for recent publications. See Appendix A for the search terms and combinations that were used to identify relevant literature.

\subsection{Definition of Selection Criteria}

This stage of the review process involves defining search and selection criteria enabling the categorization of diverse studies into relevant and non-relevant literature. The selection involved a three-stage screening process and a final inclusion criterion. The literature search in PubMed, Web of Science, and specific searches in Google and Google Scholar yielded 15,371 records. Using Citavi, duplicates were removed during importation of citation text data, which brought the number of records to 10,178. First, the records were screened by titles to eliminate literature that, by their titles, were either irrelevant or unrelated to land tenure security and health. For instance, titles such as "Where Did They Come from-Multi-Drug Resistant Pathogenic Escherichia coli in a Cemetery Environment?" and "Similarities and Differences Between Yoruba Traditional Healers (YTH) and Native American and Canadian Healers (NACH)" were removed. This step excluded 9733 records. The remaining records were screened by reading their abstracts and selecting those which referred at least to a context in which either land tenure and/or health were discussed. This yielded 95 documents, which were selected for full review (see Figure 1 for flowchart of literature search process). A study was considered relevant literature for inclusion in this review, only if their abstracts suggested a focus on land tenure (in)security and variants of the term (including housing tenure, homeownership, tenure regularization, homelessness, housing security, land security, housing instability, etc.) and health variables including, sanitation, pollution, diseases, and illnesses. By full review, we mean reading and extracting data from the abstracts, introduction, findings, and conclusion of each study.

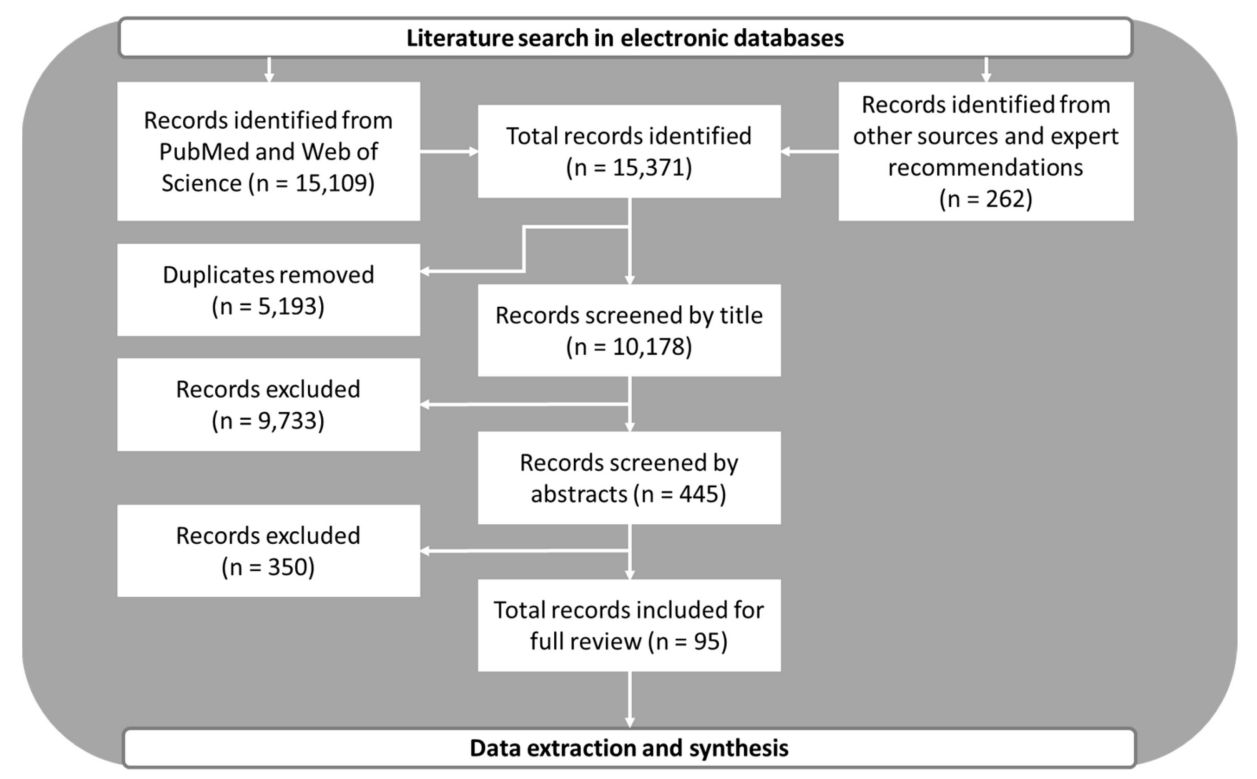

Figure 1. Flowchart of literature search process.

\subsection{Summary and Synthesis}

Green et al. [93] recommends taking notes on each of the literature works reviewed and constructing a short overview of the research topic based on the literature. Accordingly, we designed a data extraction sheet in Excel, with which we extracted data and took notes from each of the studies reviewed. The data extraction sheet was designed to retrieve data on the objective of each study, the methods used, the variables that were investigated, the findings relating to land tenure security and health, and a section for author note and comments. Relying on thematic analysis, we explored themes within the findings by color-coding the data extraction sheet according to themes, grouping and synthesizing 
the findings of each study to derive themes that address the connection between land tenure security and health. From this literature synthesis, we present our findings in the next section.

\section{The Land Tenure Security and Health Nexus: Pathways of Association}

The review identified four pathways through which land tenure security and health are connected-physical space and basic infrastructure, environmental conditions and stewardship, psycho-ontological security, and social cohesion. Our findings demonstrate that land tenure security, or the deprivation of it, fosters or hinders the above pathways and influences the severity or mildness of health burdens and health outcomes of individuals and urban neighborhoods.

\subsection{Land Tenure Security, Physical Space, and Basic Infrastructure}

One way to improve the living conditions and health of urban dwellers is the provision of affordable and secure shelter with access to basic services and amenities. Yet, literature shows that over one billion people are living in urban (mostly informal) areas that lack access to space and basic infrastructure and services [38]. Several scholars have simply attributed health outcomes in these areas to the provision of water, sanitation, and hygiene facilities through physical planning $[96,97]$. On the contrary, the solutions to poor health, material deprivation, lack of access to health care, clean water, and sanitation are not merely in the provision of these resources but in the access to these resources and the social milieu within which they are provided [98]. One such context to view the provision of infrastructure and basic services is land tenure. There is a connection between a person's land tenure status and health, which is mediated by the link between tenure and access to infrastructure and basic services [99]. Lack of secure tenure either leaves people with no other options but to settle on hazardous lands, deprives them access to basic amenities in cities, or disincentivizes people from undertaking private investment in infrastructure to improve their living conditions. Unsatisfactory land tenure relations and insecurity can impede investment in housing improvement, water, sanitation, and other services [100]. Moreover, viewed differently, the provision of these infrastructure by central government can lead to dispossessions and exposure to harsh living conditions where there is no security of tenure [101]. Merely providing infrastructure in urban neighborhoods is not enough to improve the living conditions and health of the inhabitants. Instead, people need secure tenure to access and enjoy these infrastructure and services. The lack of land tenure security means that people end up occupying high-risk land on which infrastructure and service provision are less attractive or not feasible at all. Another way in which insecure tenure affects the provision of infrastructure and services is the revenue leakages that are also associated with areas characterized by undefined and secure property rights. Low government revenues from these areas also mean low budgetary allocations for the provision of health and other infrastructure and services [102]. From a data perspective, the instability of persons and neighborhoods without secure tenure also presents a data problem, which is required for undertaking infrastructural and service interventions to improve health or reduce health burdens [103]. Beyond governments providing infrastructure and services, self-help provision, investment, and improvement of basic infrastructure and services are inhibited by the absence of secure tenure. This makes a difference in livelihood and health outcomes as it, for example, limits private provision of sanitation in deprived urban neighborhoods [100]. Neighborhoods with ample physical infrastructure and amenities such as housing, water supply, sanitation, basic drainage, and public space are less prone to poor health and disease contagion. Bhardwaj et al. [104] debunked claims of urban density rendering cities vulnerable to diseases and posit that density is not the problem but infrastructure. To leverage the health benefit of infrastructure however requires that people have secure tenure to access physical infrastructure and amenities to lower their health risks. Giving people secure tenure rights not only enables access to state provided infrastructure but can unleash investment in private infrastructure [105-107], which is an incremental 
and pro-poor approach to meeting infrastructure needs of urban neighborhoods, given that it is expensive to implement all the infrastructure needs of urban areas. Thus, when people have secure tenure, they can improve their living conditions and health through undertaking self-supportive basic infrastructural investment and improvement. According to Gomes et al. [108], land tenure insecurity inhibits the construction of definitive houses, which in their view makes homes vulnerable to Chagas diseases.

\subsection{Land Tenure Security, Environmental Conditions, and Stewardwardship}

The link between land tenure security and health is manifest in the complex connection between land tenure security, environmental justice, pro-environmental behaviors, and investment to improve environmental conditions. Urban areas are generators of polluting emissions, vast quantities of solid and human waste that contribute to health risks, and can have serious impacts on public health [99]. People without secure tenure who tend to live near environmentally hazardous facilities feel these impacts disproportionately. This is because either the lack of access to land pushed them to settle for whatever land is available regardless of dangers, or the absence of secure rights made them unable to defend their environmental rights and demand justice from other users of the environment. The insecurity of tenure also means that people are vulnerable to climate shocks and disaster $[109,110]$. Precarious land rights or land tenure insecurity make people vulnerable to environmental injustice. Without strong or secure land rights, people are unable to resist injustice. When tenure is secure, individuals can push back environmental hazards in defense of their health and environmental rights [111]. Security of tenure is therefore a precondition for environmental justice, the lack of which inhibits the ability of people to take transformative action that can either improve environmental justice or reduce environmental injustices that affect their health [112]. Transformative actions stimulate individuals to undertake investments that improve their environments, to undertake environmental management practices, or to participate in collective environmental activities to reduce their health burden. Secure tenure confers on people environmental rights, responsibility, and restrictions, i.e., rights to enjoy environmental benefits and defend their environments from pollution by others, responsibility to be environmentally accountable to others, and restrictions to act within the confines of environmental laws and other people's environmental rights. The sense of ownership, control, and responsibility that comes with land tenure security is the driving motivation for investing in environmental improvement which fosters good health $[52,106,107,113]$. Secure tenure also ensures participation in collective activities for better urban environmental conditions, which affects health. Compared to their counterparts who have secured tenure, people without secure tenure lack attachment with their surroundings and do not feel responsible for maintaining healthy environmental practices [114]. Therefore, land tenure security holds an important place in environmental health. First, it provides rights to resist unfair distribution of environmental benefits and burdens. Secondly, it confers responsibility on people to invest in their environments and act within environmentally permissible boundaries.

\subsection{Land Tenure Security and Psycho-Ontological Security}

A third pathway through which land tenure security connects with health is the psychological security afforded by security over land. Land tenure security contributes to improved health and well-being through two mechanisms: first, by allowing people to have a secure home, it allows some degree of ontological security. Second, it reduces stress associated with insecure tenure and frequent relocations [115]. Land tenure insecurity undermines the ontological security pertaining to the deep psychological need that all human beings have for a home or other locale to operate as a site of constancy, routine, and control in their lives [116]. Thus, the confidence of a person in the continuity of their self-identity and the constancy of the surrounding social and material environments of action [117]. On the contrary, secure tenure commands prestige, autonomy, and protection, which affect the individual's mental state and health. Mental health effects of tenure 
are not only related to the patterns of stress and anxiety associated with insecurity; the instability of tenure over a reasonable period also means that there is a regular fracturing of social ties and networks which affects a person's psychological being [47]. Insecurity of tenure is detrimental to the sense of stability and belonging of individuals. People who make multiple transitions due to instability of tenure are observed to show worse mental health outcomes as psychological distress increases with the number of transitions [118]. Literature generally supports the notion that homeownership is associated with better psychological health as it offers greater feelings of security compared with other forms of tenure [78,119-122] which are characterized by lack of control and threats of eviction. Owning a home reduces depressive symptoms. Park et al. [55] posit that compared with homeowners, renters are more likely to have depressive symptoms and poor selfrated health. This is mediated by the health effects of housing unaffordability which was observed among renters. Gentrification and residential displacements due to high rents exerts psychological stressors, which affect a person's mental health. A study showed that women who reported depressive symptoms attributed their health circumstances to high mobility, eviction, and problems paying rent [123]. While these studies limit tenure to ownership and leasehold, they agree in their stance that the security and control offered by ownership and the instability associated with rental housing is the distinguishing feature of tenure that affects the psychological health of owners and renters differently. As observed in the city of Belo Horizonte in Brazil, a tenure regularization project led to a downward trend in stress-related homicides in regularized slums, compared to the non-regularized slum settlements [124]. Similarly, a study of migrant populations in urban China indicated that persons with informal tenure have the highest level of perceived stress and worse mental health compared to their counterparts with formal tenure [125]. All these findings suggest that land tenure insecurity predispose holders of such volatile rights to psychosocial distress and diminishing ontological security. Although the literature has dominantly emphasized on homeownership and rental which are forms of tenure [78,119,120,122], it shrouds the nuances of tenure especially in developing country contexts where focus is put on individual land access rather than mortgage and investor supplied housing. Hence, it is relevant to investigate these linkages in different contexts where socio-cultural dynamics present multiple forms of tenure along the tenure continuum.

\subsection{Land Tenure Security and Social Cohesion}

Land tenure security gives people a sense of autonomy, social identity, and control over their living environment resulting in increased residential stability and reduced stress [115]. The increased residential stability and length of residence contributes to social cohesion, which influences the individual's social health. Social cohesion, social capital, and social networks are important to the material, psychosocial, and political aspects of empowerment that underpin social well-being and equitable health in urban settings. Observation and empirical data, mainly from high-income countries, indicate improvement in health outcomes following improvements in social support and social network [6]. By reducing residential mobility, land tenure security ensures that social ties and networks are maintained. Tenure instabilities deprive people from resources, and from opportunities for socializing. Moreover, the possibility of eviction at any time evokes anxiety, which makes it difficult to retain social ties. On the contrary, guaranteed tenure security creates a foundation for social engagement and strong friendships [126]. This contributes to individual self-esteem, sense of belonging, and community participation. Social mechanisms rely on social interactions between groups to influence behaviors and attitudes, formation of social networks that transmit information, resources, and social support which influences health outcomes [127]. Neighborhoods characterized by informality and insecurity of tenure suffer blemish of place and poor neighborhood reputation [128]. This affects individuals' sense of identity and social status, which leaves a feeling of social exclusion and social stigma. The way these neighborhoods are viewed by different groups including residents and policy makers affects social service provision 
which has an influence on health [128]. More formal and secure forms of tenure are associated with enhanced neighborhood reputation which has led many scholars to argue that reducing concentrations of informal and less secure tenures and increasing more mixed communities with secure rights reduces social stigma and exclusion which improves people social well-being and health $[127,128]$. Thus, secure tenure fosters social health through building strong social networks, sense of community, and participation such as in communal work and clean up campaigns for the social good. Where there is no secure tenure owing to gentrification and residential displacements, households lose the essential security and sense of knowing they can call a place home [116], and this affects a person's social and psychological well-being.

\section{Conceptual Framework for Land Tenure Security and Health Nexus}

Drawing evidence from the preceding section, we propose that looking into concerns and variations of land tenure security has the potential to address, promote, make resilient, or render susceptible multiple dimensions of neighborhood and individual health through four pathways described in the conceptual framework as displayed in Figure 2. Traditional biomedical frameworks for addressing health and diseases assume that health outcomes are a result of deviations from measurable biological factors. Hence, they leave little room for the social, environmental, psychological, and behavioral dimensions of health [129]. In contrast, social epidemiological and biopsychosocial frameworks acknowledge that a basis for understanding the determinants of health and arriving at appropriate interventions for addressing health patterns is that the social context in which a person lives is taken into account $[18,57,129]$. Land tenure security represents both a social context and social position that influence health through multiple dimensions and outcomes. From a health promotion perspective, land tenure security can be viewed as a multidimensional, behaviorally based socio-environmental intervention that has the potential to modify factors that affect health outcomes.

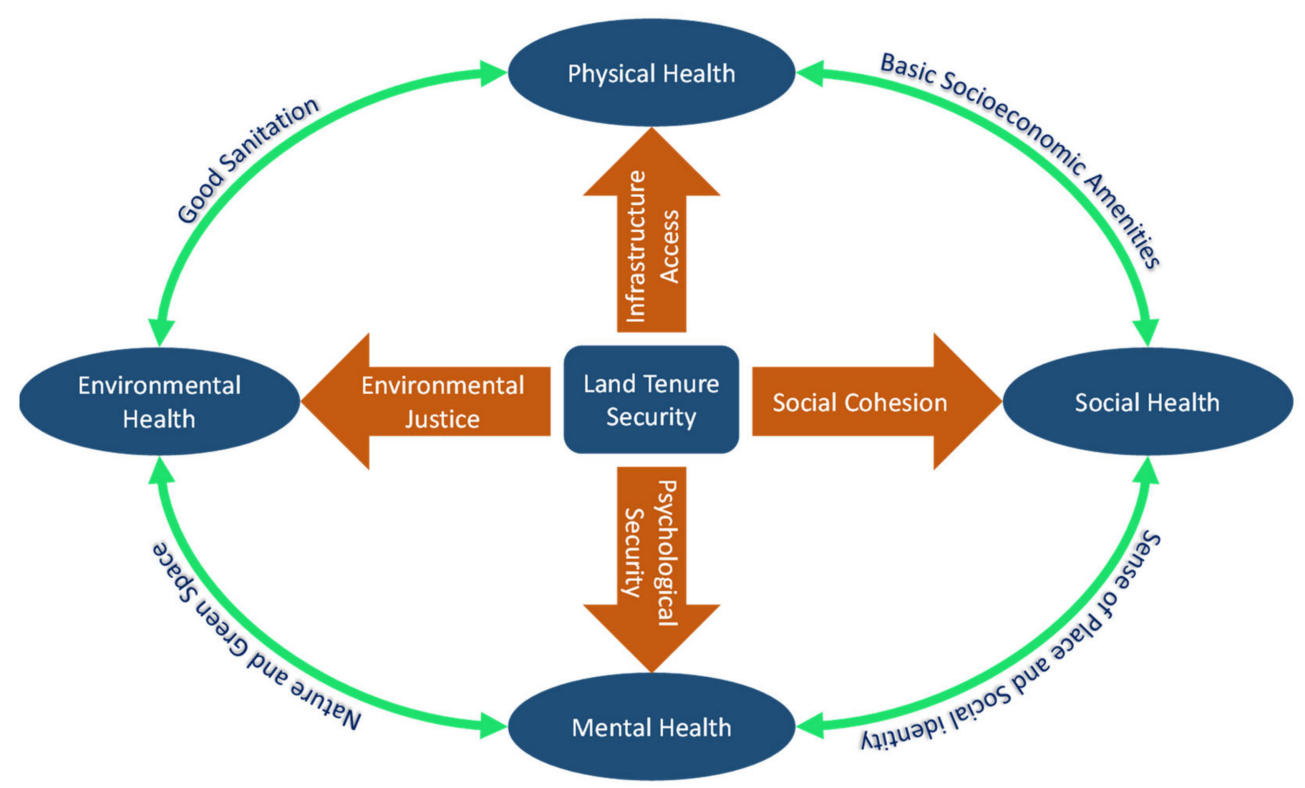

Figure 2. Conceptual framework for land tenure security and health nexus.

Land tenure security has been shown to provide psycho-ontological security which reduces the stress and anxiety associated with tenure insecurity to deliver positive mental health outcomes $[47,55,115,116,122]$. Reduced residential mobility and sustained social ties associated with tenure security is shown to promote social cohesion, keep families together, reduce place blemishes and social stigmatization, and enable households to focus on longterm goals such as personal relationships, career development, child health, and human capital development which collectively impact social health [115]. Similarly, secure tenure 
has been demonstrated to facilitate access to and investment in space improvement, basic infrastructure, and services such as water, sanitation, and hygiene facilities that can promote people's physical health $[56,99,101,102,104,130-132]$. Finally, land tenure security has been shown to be a socially empowering intervention that empowers people with environmental rights, instills environmental responsibility, and imposes environmental restrictions, which collectively enable individuals to lessen their environmental burdens or improve resilience against environmental ills and injustices. Thus, land tenure security empowers people to protect their living environments, while using their own environs responsibly and within permissible limits to improve environmental health [109-112,114]. Land tenure security influences health outcomes by tapping into the socio-physical environment and distal factors such as environmental justice, psychological security, social cohesion, and infrastructure access to modify health outcomes of neighborhoods and individuals. Our conceptual framework linking land tenure security and health was informed by social determinants of health thinking, underscored by three theories of social production of health - psychosocial theory [88,89], social production of disease theory [90], and eco-social theory [60].

From Figure 2, land tenure security, a socio-environmental intervention, guarantees psychological security to promote mental health. It does this by reducing psychosocial stresses and anxieties associated with tenure insecurities and threats of evictions, be it by state authorities through expropriation, planned land uses, development controls, building codes/standards, others claiming rights to land or natural disaster-induced tenure insecurity. Land tenure security ensures environmental justice, enabling a rights-based empowerment to individuals and neighborhoods to take transformative environmental actions against environmental injustices, such as pollution and insanitary conditions, to promote environmental health. Similarly, land tenure security promotes physical health through an infrastructure and service pathway by providing legitimacy and entitlement to use existing state-provided infrastructure or incentivizing individuals and households to undertake private investment in basic infrastructure and life-sustaining services. Finally, land tenure security promotes social health through social cohesion, leveraging on the sustainable social ties and networks afforded by residential stability. Improvements in any dimension of health is improvement in other dimensions of health. With appropriate tenure responsive interventions and policy, land tenure security will ensure good sanitation, access to basic socio-economic amenities, create a sense of place and social identity, and access to nature and green space. Good sanitation impacts environmental and physical health, basic socio-economic amenities impact physical and social health, a sense of place and social identity affects social and mental health, and access to nature and green space affects mental and environmental health.

\section{Conclusions, Implications, and Recommendations for Further Research}

To tackle the health burden of urban areas, there is the need to address the health risks, challenges of urbanization which define the social context within which people live, and the stratified social positions assigned to individuals and neighborhoods by these risks, challenges, and opportunities. Poor health and health inequalities can be addressed by focusing attention on the creation, management, and improvement of the socio-environmental settings in which people live [48]. In this paper, we set out to explore land tenure security both as a socio-environmental setting and a social position and its connection to health. Drawing upon results of 95 gray and peer-reviewed articles, this paper demonstrated that land tenure security influences health via four pathways-providing psycho-ontological security, enabling environmental justice, infrastructure access and fostering social cohesion. These four pathways promote four dimensions of health namely mental, environmental, physical, and social health. Underscored by social production of health theories, we framed land tenure security as a social determinant of health and accordingly proposed a conceptual framework for understanding the nexus between land tenure security and health. 
The paper addressed a critical gap in land management, urban and global health literature, where the health impacts of land tenure (in)security are less understood and understudied, despite policy and intellectual discourses in the wake of coronavirus disease 2019 (COVID-19) which points to greater health burden of areas characterized by smacks of land tenure insecurity. The connection between land tenure security and health is a reality we live with, manifest in our daily encounter and interaction with informal settlements, and unsightly scenes of filth, and continuous (re)emergence of communicable and noncommunicable diseases in our cities. This paper and subsequent studies advance a course for achieving the new urban agenda and key sustainable development goals including no poverty, zero hunger, life on land, sustainable cities, and clean water and sanitation, all of which feed into health and well-being.

Advancing the course of land tenure security and health nexus implies abandoning the mono-disciplinary silo approaches and opt for integrative inter-disciplinary approaches, which connect land tenure security and health. Land tenure policies and interventions must be designed to target and achieve health specific goals and outcomes. Similarly, health policies must integrate tenure security in the design of health interventions in a bid to deliver health equity. This means in practice that health and land professionals and institutions must collaborate and work together to deliver a common goal of good health. Thus, cities must work towards adopting health-in-all-policies with the ultimate objective of redressing social structures and factors such as variations in land tenure that generate inequalities in health and health outcomes.

The findings from the current study also open up further research avenues. First, despite the emerging evidence of a link between land tenure security and health, there are still no studies that empirically measure this connection. Hence, there is the need to go further to investigate empirically if there is a connection between land tenure and health and if tenure variations explain variations in health outcomes and disease outbreaks. Secondly, the findings open avenues for exploring tenure security and environmental health justice in cities. Land tenure security is a rights-based approach to justice. Therefore, wherever land tenure insecurities are served, environmental injustices are served as well. A third research avenue is the prospect of this study to inspire research into the mediating role of urban redevelopment, urban greening, and health in cities. Whereas urban greening and redevelopments have health justifications and benefits, they also carry the risk of gentrification and inequities in access, where there are insecure tenure rights. Thus, research is needed to understand how secure tenure can help mitigate the unintended health effects of urban redevelopments and associated gentrification. The findings also open up a fourth avenue for investigating variations in land tenure security in connection to health inequalities in cities. To this extent, neighborhood land tenure security patterns could be studied and analyzed spatially to understand health and disease patterns and distribution in cities. A key driver for activating the link between land tenure security and health is policy. Thus, the study also opens a fifth research dimension that would seek to understand the interactions of urban land tenure policy, urban planning policy and health policy to deliver equitable health outcomes in cities.

This study is only the beginning of a new research agenda to rethink urban health from a land tenure security lens. Moving beyond theory, a further step of this study is to develop a tenure security "health insults" index based on which an empirical investigation of the connection between land tenure security and health outcomes is possible.

Author Contributions: This manuscript is a part of ongoing PhD. research. The PhD. candidate (W.D.) and the supervisor (W.T.d.V.) made their respective contributions to the manuscript as follows: Conceptualization, W.D.; methodology, W.D.; validation, W.T.d.V.; formal analysis, W.D.; investigation, W.D.; resources, W.D. and W.T.d.V.; data curation, W.D.; writing-original draft preparation, W.D.; writing-review and editing, W.T.d.V.; visualization, W.D.; supervision, W.T.d.V. All authors have read and agreed to the published version of the manuscript.

Funding: This research received no external funding. 
Institutional Review Board Statement: Not applicable.

Informed Consent Statement: Not applicable.

Data Availability Statement: Not applicable.

Acknowledgments: This study was carried out while undertaking a Ph.D. research program at the Chair of Land Management, Technical University of Munich (TUM). We wish to express our appreciation to the Konrad Adenauer Stiftung (KAS) for funding the doctoral studies. We would also like to thank the mentor of the Ph.D. candidate (U.E. Chigbu) for his mentorship, E.D. Kuusaana, fellow doctoral candidates, and reviewers whose intellectual discussions and constructive comments helped to improve the paper.

Conflicts of Interest: The authors declare no conflict of interest.

\section{Appendix A}

Table A1. Search terms.

\begin{tabular}{|c|c|c|c|}
\hline Search Terms \& Strategy & PubMed Records & Web of Science Records & Google and Google Scholar \\
\hline "Land tenure" and "urban health" & 42 & 33 & - \\
\hline "Land tenure" and "health" & 0 & 64 & - \\
\hline "Land rights" and "health" & 26 & 0 & - \\
\hline "Land rights" and "urban health" & 2 & 0 & - \\
\hline "Built environment" and "diseases" & 339 & 589 & - \\
\hline "Built environment" and "urban health" & 183 & 82 & - \\
\hline "Land ownership" and "health" & 84 & 77 & - \\
\hline "Land security" and "health outcomes" & 4 & 0 & - \\
\hline "Land tenure" and "health vulnerability" & 22 & 0 & - \\
\hline "Housing tenure" and "health" & 382 & 187 & - \\
\hline "Built environment" and "health" & - & 3650 & - \\
\hline "Built environment" and "health outcomes" & 921 & 364 & - \\
\hline "Urban health vulnerability" & 3022 & 1 & - \\
\hline "Built environment" and "health vulnerability" & 299 & 0 & - \\
\hline Built environment and diseases & 1135 & 0 & - \\
\hline "Land" and "health nexus" & 2 & 8 & - \\
\hline "Land tenure" and "disease" & 22 & 16 & - \\
\hline "Land rights" and "diseases" & 4 & 0 & - \\
\hline Land tenure health nexus & 165 & 10 & - \\
\hline Land tenure disease nexus & 47 & 0 & - \\
\hline Land access health nexus & 0 & 0 & - \\
\hline "Land tenure" and "health" & 122 & 87 & - \\
\hline "Land tenure security" and "environment" & 1 & 8 & - \\
\hline "Land tenure security" and "environmental" & 1 & 24 & - \\
\hline "land tenure" and "environmental health" & 2 & 4 & - \\
\hline "Land tenure" and "environment" & 119 & 251 & - \\
\hline "Land tenure" and "diseases" & 24 & 22 & - \\
\hline "Housing tenure" and "mental health" & 46 & 63 & - \\
\hline "Land tenure" and "mental health" & 1 & 2 & - \\
\hline "Land ownership" and "environmental health" & 4 & 1 & - \\
\hline
\end{tabular}


Table A1. Cont.

\begin{tabular}{|c|c|c|c|}
\hline Search Terms \& Strategy & PubMed Records & Web of Science Records & Google and Google Scholar \\
\hline "Land tenure" and "social health" & 3 & 2 & - \\
\hline "Housing tenure" and "environmental health" & 3 & 2 & - \\
\hline "Land" and "social health & 26 & 36 & - \\
\hline "Housing tenure" and "physical health" & 8 & 11 & - \\
\hline "Homelessness" and "physical health" & 151 & 193 & - \\
\hline "Homelessness" and "social health" & 11 & 15 & - \\
\hline "Homelessness" and "environmental health" & 26 & 4 & - \\
\hline "Informal tenure" and "health" & 338 & 0 & - \\
\hline "Informal tenure" and "environmental health" & 8 & 0 & - \\
\hline "Slums" and "social inclusion" & 3 & 10 & - \\
\hline "Slums" and "social exclusion" & 9 & 26 & - \\
\hline "Housing tenure" and "social exclusion" & 3 & 11 & - \\
\hline "Informal settlements" and "health" & 365 & 414 & - \\
\hline $\begin{array}{l}\text { "Informal settlements" and } \\
\text { "environmental health" }\end{array}$ & 25 & 11 & - \\
\hline "Informal settlements" and "physical health" & 5 & 7 & - \\
\hline "Informal settlements" and "social health" & 3 & 3 & - \\
\hline "Informal settlements" and "mental health" & 22 & 33 & - \\
\hline "Sense of place" and "health" & 89 & 146 & - \\
\hline "Informal settlements" and "sense of place" & 3 & 0 & - \\
\hline "Informal settlements" and "social exclusion" & 3 & 11 & - \\
\hline "Informal settlements" and "social inclusion" & 3 & 8 & - \\
\hline "Informal settlements" and "diseases" & 67 & 55 & - \\
\hline "Land tenure" and "social identity" & 0 & 5 & - \\
\hline "Land tenure" and "social exclusion" & 0 & 6 & - \\
\hline "Land tenure" and "social inclusion" & 0 & 6 & - \\
\hline "Land tenure security" and "sense of place" & 0 & 1 & - \\
\hline "Land tenure" and "sense of place" & 0 & 2 & - \\
\hline "Land tenure" and "cultural identity" & 0 & 4 & - \\
\hline "Housing tenure" and "social inclusion" & 0 & 4 & - \\
\hline $\begin{array}{c}\text { Specific hand searches in Google and } \\
\text { Google Scholar }\end{array}$ & - & - & 262 \\
\hline
\end{tabular}

\section{References}

1. Bodo, T. Rapid urbanisation: Theories, causes, consequences and coping strategies. Ann. Geogr. Stud. 2019,2 , 32-45.

2. Castells-Quintana, D.; Wenban-Smith, H. Population Dynamics, Urbanisation without Growth, and the Rise of Megacities. J. Dev. Stud. 2020, 56, 1663-1682. [CrossRef]

3. Connolly, C.; Keil, R.; Ali, S.H. Extended urbanisation and the spatialities of infectious disease: Demographic change, infrastructure and governance. Urban. Stud. (Edinb. Scotl.) 2021, 58, 245-263. [CrossRef]

4. United Nations. World Urbanization Prospects: The 2018 Revision; United Nations: New York, NY, USA, 2019.

5. Vlahov, D.; Freudenberg, N.; Proietti, F.; Ompad, D.; Quinn, A.; Nandi, V.; Galea, S. Urban as a determinant of health. J. Urban Health Bull. N.Y. Acad. Med. 2007, 84, i16-i26. [CrossRef] [PubMed]

6. De Snyder, V.N.S.; Friel, S.; Fotso, J.C.; Khadr, Z.; Meresman, S.; Monge, P.; Patil-Deshmukh, A. Social conditions and urban health inequities: Realities, challenges and opportunities to transform the urban landscape through research and action. J. Urban Health Bull. N.Y. Acad. Med. 2011, 88, 1183-1193. [CrossRef] [PubMed] 
7. Godfrey, R.; Julien, M. Urbanisation and health. Clin. Med. 2005, 5, 137-141. [CrossRef]

8. Vearey, J.; Palmary, I.; Thomas, L.; Nunez, L.; Drimie, S. Urban health in Johannesburg: The importance of place in understanding intra-urban inequalities in a context of migration and HIV. Health Place 2010, 16, 694-702. [CrossRef] [PubMed]

9. Sverdlik, A. Ill-health and poverty: A literature review on health in informal settlements. Environ. Urban. 2011, 23, 123-155. [CrossRef]

10. WHO. The Economics of Social Determinants of Health and Health Inequalities: A Resource Book; World Health Organization: Geneva, Switzerland, 2013.

11. Chigbu, U.E. e-Tracking COVID-19 Disruptions to the Global Development Agenda on Land. Int. J. Environ. Sci. Nat. Resour. 2020, 26, 1-9.

12. Corburn, J.; Vlahov, D.; Mberu, B.; Riley, L.; Caiaffa, W.T.; Rashid, S.F.; Ko, A.; Patel, S.; Jukur, S.; Martínez-Herrera, E.; et al. Slum Health: Arresting COVID-19 and Improving Well-Being in Urban Informal Settlements. J. Urban Health Bull. N.Y. Acad. Med. 2020, 97, 348-357. [CrossRef]

13. Chigbu, U.E.; Onyebueke, V.U. The COVID-19 pandemic in informal settlements: (re)considering urban planning interventions. Town Plan. Rev. 2021, 92, 115-121. [CrossRef]

14. Barton, H. Land use planning and health and well-being. Land Use Policy 2009, 26, S115-S123. [CrossRef]

15. Barton, H.; Grant, M. A health map for the local human habitat. J. R. Soc. Promot. Health 2006, 126, 252-253. [CrossRef] [PubMed]

16. Grover, A.; Singh, R.B. Urban. Health and Wellbeing: Indian Case Studies/Aakriti Grover, R.B. Singh; Springer: Singapore, 2020.

17. Corburn, J. Urban Place and Health Equity: Critical Issues and Practices. Int. J. Environ. Res. Public Health 2017, 14, 117. [CrossRef] [PubMed]

18. World Health Organization (WHO). A Conceptual Framework for Action on the Social Determinants of Health; WHO: Geneva, Switzerland, 2010.

19. Corburn, J. City planning as preventive medicine. Prev. Med. 2015, 77, 48-51. [CrossRef]

20. Corburn, J. Toward the Healthy City: People, Places, and the Politics of Urban Planning; MIT Press: Cambridge, UK, 2009.

21. Arthurson, K.; Lawless, A.; Hammet, K. Urban Planning and Health: Revitalising the Alliance. Urban. Policy Res. 2016, 34, 4-16. [CrossRef]

22. Nawrath, M.; Guenat, S.; Elsey, H.; Dallimer, M. Exploring uncharted territory: Do urban greenspaces support mental health in low- and middle-income countries? Environ. Res. 2020, 194, 110625. [CrossRef]

23. Kruize, H.; van der Vliet, N.; Staatsen, B.; Bell, R.; Chiabai, A.; Muiños, G.; Higgins, S.; Quiroga, S.; Martinez-Juarez, P.; Aberg Yngwe, M.; et al. Urban Green Space: Creating a Triple Win for Environmental Sustainability, Health, and Health Equity through Behavior Change. Int. J. Environ. Res. Public Health 2019, 16, 4403. [CrossRef]

24. Labib, S.M.; Lindley, S.; Huck, J.J. Spatial dimensions of the influence of urban green-blue spaces on human health: A systematic review. Environ. Res. 2020, 180, 108869. [CrossRef] [PubMed]

25. Kim, M.; Rupprecht, C.; Furuya, K. Residents' Perception of Informal Green Space-A Case Study of Ichikawa City, Japan. Land 2018, 7, 102. [CrossRef]

26. Semeraro, T.; Scarano, A.; Buccolieri, R.; Santino, A.; Aarrevaara, E. Planning of Urban Green Spaces: An Ecological Perspective on Human Benefits. Land 2021, 10, 105. [CrossRef]

27. Gibson, L.; Rush, D. Novel Coronavirus in Cape Town Informal Settlements: Feasibility of Using Informal Dwelling Outlines to Identify High Risk Areas for COVID-19 Transmission from A Social Distancing Perspective. Jmir Public Health Surveill. 2020, 6, e18844. [CrossRef] [PubMed]

28. Seidlein, G.; von Alabaster, L.; Deen, J.; Knudsen, J. Crowding has consequences: Prevention and management of COVID-19 in informal urban settlements. Build. Environ. 2021, 188, 107472. [CrossRef]

29. Matan, A.; Newman, P.; Trubka, R.; Beattie, C.; Selvey, L.A. Health, Transport and Urban Planning: Quantifying the Links between Urban Assessment Models and Human Health. Urban. Policy Res. 2015, 33, 145-159. [CrossRef]

30. Nieuwenhuijsen, M.J. Urban and transport planning pathways to carbon neutral, liveable and healthy cities; A review of the current evidence. Environ. Int. 2020, 140, 105661. [CrossRef] [PubMed]

31. Gariazzo, C.; Carlino, G.; Silibello, C.; Renzi, M.; Finardi, S.; Pepe, N.; Radice, P.; Forastiere, F.; Michelozzi, P.; Viegi, G.; et al. A multi-city air pollution population exposure study: Combined use of chemical-transport and random-Forest models with dynamic population data. Sci. Total Environ. 2020, 724, 138102. [CrossRef]

32. Chen, S.-Y.; Chu, D.-C.; Lee, J.-H.; Yang, Y.-R.; Chan, C.-C. Traffic-related air pollution associated with chronic kidney disease among elderly residents in Taipei City. Environ. Pollut. (Barking, Essex: 1987) 2018, 234, 838-845. [CrossRef] [PubMed]

33. Opisa, S.; Odiere, M.R.; Jura, Walter, G.Z.O.; Karanja, D.M.S.; Mwinzi, P.N.M. Faecal contamination of public water sources in informal settlements of Kisumu City, western Kenya. Water Sci. Technol. A J. Int. Assoc. Water Pollut. Res. 2012, 66, $2674-2681$. [CrossRef] [PubMed]

34. Corburn, J. Urban land use, air toxics and public health: Assessing hazardous exposures at the neighborhood scale. Environ. Impact Assess. Rev. 2007, 27, 145-160. [CrossRef]

35. Winkworth, C.L. Land-use change and emerging public health risks in New Zealand: Assessing Giardia risks. New Zealand Med. J. 2010, 123, 55-66. [PubMed]

36. Kim, H. Land Use Impacts on Particulate Matter Levels in Seoul, South Korea: Comparing High and Low Seasons. Land 2020, 9, 142. [CrossRef] 
37. Durand-Lasserve, A.; Royston, L. Holding Their Ground: Secure Land Tenure for the Urban Poor in Developing Countries; Earthscan Publications: London, UK, 2002.

38. UN-Habitat. WORLD CITIES REPORT 2020: The Value of Sustainable Urbanization; United Nations Human Settlements Programme: Nairobi, Kenya, 2020.

39. Dachaga, W.; Chigbu, E.U. Understanding tenure security dynamics in resettlement towns: Evidence from the Bui Resettlement Project in Ghana. JPLM 2020, 1, 38-49.

40. Chigbu, U.E. Tenure Responsive Land-Use Planning as a Tool for Improving Quality of Life: The Perspective of Sub-Saharan Africa. In Handbook of Quality of Life and Sustainability, 1st ed.; Martinez, J., Mikkelsen, C.A., Phillips, R., Eds.; Springer International Publishing: Cham, Germany, 2021; pp. 17-33.

41. Chigbu, U.; Alemayehu, Z.; Dachaga, W. Uncovering land tenure insecurities: Tips for tenure responsive land-use planning in Ethiopia. Dev. Pract. 2019, 29, 371-383. [CrossRef]

42. Schnake-Mahl, A.S.; Jahn, J.L.; Subramanian, S.V.; Waters, M.C.; Arcaya, M. Gentrification, Neighborhood Change, and Population Health: A Systematic Review. J. Urban Health Bull. N.Y. Acad. Med. 2020, 97, 1-25. [CrossRef] [PubMed]

43. Cole, H.V.S. A call to engage: Considering the role of gentrification in public health research. Cities Health 2020, 4, 278-287. [CrossRef]

44. Cole, H.V.S.; Anguelovski, I.; Baró, F.; García-Lamarca, M.; Kotsila, P.; Del Pérez Pulgar, C.; Shokry, G.; Triguero-Mas, M. The COVID-19 pandemic: Power and privilege, gentrification, and urban environmental justice in the global north. Cities Health 2020, 1-5. [CrossRef]

45. Boamah, E.F.; Amoako, C. Planning by (mis)rule of laws: The idiom and dilemma of planning within Ghana's dual legal land systems. Environ. Plan. C Politics Space 2020, 38, 97-115. [CrossRef]

46. Watson, N.L. Implications of land rights reform for Indigenous health. Med J. Aust. 2007, 186, 534-536. [CrossRef]

47. Baker, E.; Bentley, R.; Mason, K. The Mental Health Effects of Housing Tenure: Causal or Compositional? Urban. Stud. (Edinb. Scotl.) 2013, 50, 426-442. [CrossRef]

48. UN-Habitat; World Health Organisation. Integrating Health in Urban and Territorial Planning: A Sourcebook. Available online: https:/ / unhabitat.org/integrating-health-in-urban-and-territorial-planning-a-sourcebook-for-urban-leaders-health-and (accessed on 23 December 2020).

49. Sena, A. Land Under Pressure-Health Under Stress. Available online: https://knowledge.unccd.int/publication/land-underpressure-health-under-stress (accessed on 8 February 2021).

50. Choudhury, P.; Ghosh, R.K.; Sindhi, S. COVID-19 Crisis, Pandemic Resilience and Linkages to Land: An Exposition; Working Papers id:13058; eSocialSciences: New Mumbai, India, 2020.

51. Tseng, T.-W.J.; Robinson, B.E.; Bellemare, M.F.; BenYishay, A.; Blackman, A.; Boucher, T.; Childress, M.; Holland, M.B.; Kroeger, T.; Linkow, B.; et al. Influence of land tenure interventions on human well-being and environmental outcomes. Nat. Sustain. 2021, $4,242-251$.

52. Nyametso, J.K. Resettlement of Slum Dwellers, Land Tenure Security and Improved Housing, Living and Environmental Conditions at Madina Estate, Accra, Ghana. Urban. Forum 2011, 23, 343-365. [CrossRef]

53. Allendorf, K. Do Women's Land Rights Promote Empowerment and Child Health in Nepal? World Dev. 2007, 35, 1975-1988. [CrossRef]

54. Victora, C.G.; Vaughan, J.P. Land ownership and infant health in Rio Grande do Sul: Relationship between agricultural production, malnutrition and mortality. Rev. Bras. De Estud. De Popul. 1987, 4, 127-151.

55. Park, G.-R.; Jung, Y. Housing insecurity and health among people in South Korea: Focusing on tenure and affordability. Public Health 2019, 171, 116-122. [CrossRef]

56. Nyametso, J.K. Improvement of Squatter Settlements: The link between tenure security, access to housing, and improved living and environmental conditions: Improvement of Squatter Settlements: The Link between Tenure Security, access to Housing, and Improved Living and Environmental Conditions. Ph.D. Thesis, University of Otago, Dunedin, New Zealand, 2011.

57. Ansari, Z.; Carson, N.J.; Ackland, M.J.; Vaughan, L.; Serraglio, A. A public health model of the social determinants of health. Soz. Und. Prav. 2003, 48, 242-251. [CrossRef] [PubMed]

58. DiClemente, R.J.; Crosby, R.A.; Kegler, M.C. Emerging Theories in Health Promotion Practice and Research, 2nd ed.; Jossey-Bass: San Francisco, CA, USA, 2009.

59. Berkman, L.F.; Kawachi, I.; Glymour, M.M. Social Epidemiology; Oxford University Press: Oxford, UK, 2014.

60. Krieger, N. Theories for social epidemiology in the 21st century: An ecosocial perspective. Int. J. Epidemiol. 2001, 30, 668-677. [CrossRef] [PubMed]

61. Adler, M.A. Land Tenure, Archaeology, and the Ancestral Pueblo Social Landscape. J. Anthropol. Archaeol. 1996, 15, 337-371. [CrossRef]

62. Payne, G. Urban land tenure policy options: Titles or rights? Habitat Int. 2001, 25, 415-429. [CrossRef]

63. Pierce, J. Reinvigorating the Concept of Land Tenure for American Urban Geography. Geogr. Compass 2010, 4, 1747-1757. [CrossRef]

64. Food and Agriculture Organization of the United Nations (FAO). Land Tenure and Rural Development; Food and Agriculture Organization of the United Nations: Rome, Italy, 2002. 
65. Kuhnen, F. Man and Land: An Introduction into the Problems of Agrarian Structure and Agrarian Reform; Breitenbach: Saarbrucken, Germany, 1982.

66. Dekker, H. Pursuit of Land Tenure Security; Leiden University Press Imprint; Amsterdam University Press: Amsterdam, The Netherlands, 2006.

67. Arnot, C.D.; Luckert, M.K.; Boxall, P.C. What Is Tenure Security? Conceptual Implications for Empirical Analysis. Land Econ. 2011, 87, 297-311. [CrossRef]

68. Augustinus, C. Handbook on Best Practices, Security of Tenure, and Access to Land Implementation of the Habitat Agenda; United Nations Human Settlements Programme: Nairobi, Kenya, 2003.

69. Van Gelder, J.-L. What tenure security? The case for a tripartite view. Land Use Policy 2010, 27, 449-456. [CrossRef]

70. Barry, M.; Augustinus, C. Framework for Evaluating Continuum of Land Rights Scenarios; UN-Habitat: Nairobi, Kenya, 2016.

71. Whittal, J. A New Conceptual Model for the Continuum of Land Rights. South Afr. J. Geomat. 2014, 3, 13-32.

72. de Soto, H. The Mystery of Capital: Why Capitalism Triumphs in the West. and Fails Everywhere Else, 1st ed.; Basic Books: New York, NY, USA, 2006; p. 2000.

73. Deininger, K.W. Land policies for growth and poverty reduction; World Bank: Washington, DC, USA; Oxford University Press: Oxford, UK, 2003.

74. Bruce, J.W.; Migot-Adholla, S.E. Searching for Land Tenure Security in Africa; Kendall/Hunt: Dubuque, IA, USA, 1994.

75. Van Gelder, J.-L. Feeling and thinking: Quantifying the relationship between perceived tenure security and housing improvement in an informal neighbourhood in Buenos Aires. Habitat Int. 2007, 31, 219-231. [CrossRef]

76. Bircher, J. Towards a dynamic definition of health and disease. Med. Health Care Philos 2005, 8, 335-341. [CrossRef] [PubMed]

77. Meade, M.S.; Emch, M. Medical Geography, 3rd ed.; Guilford: New York, NY, USA; London, UK, 2010.

78. Ellaway, A.; Macdonald, L.; Kearns, A. Are housing tenure and car access still associated with health? A repeat cross-sectional study of UK adults over a 13-year period. BMJ Open 2016, 6, e012268. [CrossRef] [PubMed]

79. Victora, C.G.; Vaughan, J.P. Land tenure patterns and child health in southern Brazil: The relationship between agricultural production, malnutrition and child mortality. Int. J. Health Serv. Plan. Adm. Eval. 1985, 15, 253-274. [CrossRef]

80. Hambling, T.; Weinstein, P.; Slaney, D. A review of frameworks for developing environmental health indicators for climate change and health. Int. J. Environ. Res. Public Health 2011, 8, 2854-2875. [CrossRef] [PubMed]

81. Garchitorena, A.; Sokolow, S.H.; Roche, B.; Ngonghala, C.N.; Jocque, M.; Lund, A.; Barry, M.; Mordecai, E.A.; Daily, G.C.; Jones, J.H.; et al. Disease ecology, health and the environment: A framework to account for ecological and socio-economic drivers in the control of neglected tropical diseases. Philos. Trans. R. Soc. B Biol. Sci. 2017, 372. [CrossRef] [PubMed]

82. Smyth, A.J.; Dumanski, J. A framework for evaluating sustainable land management. Can. J. Soil. Sci. 1995, 75, 401-406. [CrossRef]

83. Thomas, R.; Reed, M.; Clifton, K.; Appadurai, N.; Mills, A.; Zucca, C.; Kodsi, E.; Sircely, J.; Haddad, F.; Hagen, C.; et al. A framework for scaling sustainable land management options. Land Degrad. Dev. 2018, 29, 3272-3284. [CrossRef]

84. DeVries, W.T.; Bugri, J.T.; Mandhu, F. Responsible and Smart Land Management Interventions: An. African Context/Edited by Walter Timo de Vries, John Tiah Bugri, and Fatima Mandhu, 1st ed.; CRC Press: Boca Raton, FL, USA, 2020.

85. Deininger, K.W.; Selod, H.; Burns, A. The Land Governance Assessment Framework: Identifying and Monitoring Good Practice in the Land Sector; World Bank: Washington, DC, USA, 2012.

86. Uwayezu, E.; de Vries, W.T. Exploring the connection between spatial justice and land tenure security: Insights from inclusive urban (re)development schemes in Recife, Brazil. Geo. J. 2020, 1-22. [CrossRef]

87. Chigbu, U.E.; Schopf, A.; de Vries, W.T.; Masum, F.; Mabikke, S.; Antonio, D.; Espinoza, J. Combining land-use planning and tenure security: A tenure responsive land-use planning approach for developing countries. J. Environ. Plan. Manag. 2017, 60, 1622-1639. [CrossRef]

88. Cassel, J. The contribution of the social environment to host resistance. The Fourth Wade Hampton Frost Lecture. 1976. Am. J. Epidemiol. 1995, 141, 798-814, discussion 797. [CrossRef]

89. Marmot, M.; Wilkinson, R.G. Psychosocial and material pathways in the relation between income and health: A response to Lynch et al. BMJ (Clin. Res. Ed.) 2001, 322, 1233-1236. [CrossRef]

90. Conrad, P.E. Sociology of Health and Illness: Critical Perspectives; St Martin's Press: New York, NY, USA, 1981.

91. Phelan, J.C.; Link, B.G.; Tehranifar, P. Social conditions as fundamental causes of health inequalities: Theory, evidence, and policy implications. J. Health Soc. Behav. 2010, 51, S28-S40. [CrossRef] [PubMed]

92. Krieger, N.; Gruskin, S. Frameworks matter: Ecosocial and health and human rights perspectives on disparities in women's health-the case of tuberculosis. J. Am. Med. Women's Assoc. (1972) 2001, 56, 137-142.

93. Green, B.N.; Johnson, C.D.; Adams, A. Writing narrative literature reviews for peer-reviewed journals: Secrets of the trade. J. Chiropr. Med. 2006, 5, 101-117. [CrossRef]

94. Alaazi, D.A.; Aganah, G.A.M. Understanding the slum-health conundrum in sub-Saharan Africa: A proposal for a rights-based approach to health promotion in slums. Glob. Health Promot. 2020, 27, 65-72. [CrossRef]

95. Adams, E.A.; Stoler, J.; Adams, Y. Water insecurity and urban poverty in the Global South: Implications for health and human biology. Am. J. Hum. Biol. Off. J. Hum. Biol. Counc. 2020, 32, e23368. [CrossRef] 
96. Ekumah, B.; Armah, F.A.; Yawson, D.O.; Quansah, R.; Nyieku, F.E.; Owusu, S.A.; Odoi, J.O.; Afitiri, A.-R. Disparate on-site access to water, sanitation, and food storage heighten the risk of COVID-19 spread in Sub-Saharan Africa. Environ. Res. 2020, 189, 109936. [CrossRef]

97. Brown, R.; Leder, K.; Wong, T.; French, M.; Ramirez-Lovering, D.; Chown, S.L.; Luby, S.; Clasen, T.; Reidpath, D.; El Sioufi, M.; et al. Improving human and environmental health in urban informal settlements: The Revitalising Informal Settlements and their Environments (RISE) programme. Lancet Planet. Health 2018, 2, S29. [CrossRef]

98. Ompad, D.C.; Galea, S.; Caiaffa, W.T.; Vlahov, D. Social determinants of the health of urban populations: Methodologic considerations. J. Urban Health Bull. N.Y. Acad. Med. 2007, 84, i42-i53. [CrossRef] [PubMed]

99. Payne, G.; Piaskowy, T.; Kuritz, L. Land Tenure in Urban Environments. Available online: https://www.land-links.org/issuebrief/land-tenure-in-urban-environments/ (accessed on 8 February 2021).

100. Cromwell, E. Land Tenure-Key Sheets for Sustainable Livelihoods Pro-Poor Infrastructure Provision-3. Available online: https:/ / www.odi.org/sites/odi.org.uk/files/odi-assets/publications-opinion-files/3199.pdf (accessed on 1 January 2021).

101. Murthy, S.L. Land security and the challenges of realizing the human right to water and sanitation in the slums of Mumbai, India. Health Hum. Rights 2012, 14, 61-73. [PubMed]

102. Durand-Lasserve, A. Informal settlements and the millennium development goals: Global policy debates on property ownership and security of tenure. Glob. Urban. Dev. 2006, 2, 1-15.

103. Wilkinson, A. Local response in health emergencies: Key considerations for addressing the COVID-19 pandemic in informal urban settlements. Environ. Urban. 2020, 32, 503-522. [CrossRef]

104. Bhardwaj, G.; Esch, T.; Lall, S.V.; Marconcini, M.; Soppelsa, M.E.; Wahba, S. Cities, Crowding, and the Coronavirus. 2020.

105. Nakamura, S. Revealing invisible rules in slums: The nexus between perceived tenure security and housing investment. Habitat Int. 2016, 53, 151-162. [CrossRef]

106. Scott, P.; Cotton, A.; Sohail Khan, M. Tenure security and household investment decisions for urban sanitation: The case of Dakar, Senegal. Habitat Int. 2013, 40, 58-64. [CrossRef]

107. Awunyo-Akaba, Y.; Awunyo-Akaba, J.; Gyapong, M.; Senah, K.; Konradsen, F.; Rheinländer, T. Sanitation investments in Ghana: An ethnographic investigation of the role of tenure security, land ownership and livelihoods. BMC Public Health 2016, 16, 594. [CrossRef] [PubMed]

108. Gomes, T.F.; Freitas, F.S.S.; Bezerra, C.M.; Lima, M.M.; Carvalho-Costa, F.A. Reasons for persistence of dwelling vulnerability to Chagas disease (American trypanosomiasis): A qualitative study in northeastern Brazil. World Health Popul. 2013, $14,14-21$. [CrossRef]

109. Lokonon, B.O.K. Land Tenure and Communities' Vulnerability to Climate Shocks: Insights from the Niger Basin of Benin. In Building a Resilient and Sustainable Agriculture in Sub-Saharan Africa., 1st ed.; Shimeles, A., Verdier-Chouchane, A., Boly, A., Eds.; Springer International Publishing AG: Cham, Switzerland; Palgrave Macmillan: London, UK, 2018; pp. 147-180.

110. Ma, C.; Smith, T. Vulnerability of Renters and Low-Income Households to Storm Damage: Evidence from Hurricane Maria in Puerto Rico. Am. J. Public Health 2020, 110, 196-202. [CrossRef] [PubMed]

111. Ashwood, L.; Diamond, D.; Walker, F. Property rights and rural justice: A study of US right-to-farm laws. J. Rural Stud. 2019, 67, 120-129. [CrossRef]

112. Busscher, N.; Parra, C.; Vanclay, F. Environmental justice implications of land grabbing for industrial agriculture and forestry in Argentina. J. Environ. Plan. Manag. 2020, 63, 500-522. [CrossRef]

113. Twerefou, D.K.; Osei-Assibey, E.; Agyire-Tetteh, F. Land Tenure Security, Investment and the Environment in Ghana. J. Dev. Agric. Econ. 2011, 36, 261-273.

114. Arifwidodo, S.D.; Chandrasiri, O. The relationship between housing tenure, sense of place and environmental management practices: A case study of two private land rental communities in Bangkok, Thailand. Sustain. Cities Soc. 2013, 8, 16-23. [CrossRef]

115. Lewis, Jeanette: How does Security of Tenure Impact on Public Housing Careers? Available online: https://www.ahuri.edu.au/ __data/assets/pdf_file/0012/3054/AHURI_RAP_Issue_78_Security_of_tenure_Synthesis.pdf (accessed on 1 January 2021).

116. Clair, A.; Hughes, A. Housing and health: New evidence using biomarker data. J. Epidemiol. Community Health 2019, 73, $256-262$. [CrossRef]

117. Bentley, R.; Baker, E.; Simons, K.; Simpson, J.A.; Blakely, T. The impact of social housing on mental health: Longitudinal analyses using marginal structural models and machine learning-generated weights. Int. J. Epidemiol. 2018, 47, 1414-1422. [CrossRef]

118. Cairney, J. Housing tenure and psychological well-being during adolescence. Environ. Behav. 2005, 37, 552-564. [CrossRef]

119. Courtin, E.; Dowd, J.B.; Avendano, M. The Mental Health Benefits of Acquiring a Home in Older Age: A Fixed-Effects Analysis of Older US Adults. Am. J. Epidemiol. 2018, 187, 465-473. [CrossRef] [PubMed]

120. Howden-Chapman, P.L.; Chandola, T.; Stafford, M.; Marmot, M. The effect of housing on the mental health of older people: The impact of lifetime housing history in Whitehall II. Bmc Public Health 2011, 11, 682. [CrossRef] [PubMed]

121. Luginaah, I.; Arku, G.; Baiden, P. Housing and health in Ghana: The psychosocial impacts of renting a home. Int. J. Environ. Res. Public Health 2010, 7, 528-545. [CrossRef]

122. Daoud, N.; Matheson, F.I.; Pedersen, C.; Hamilton-Wright, S.; Minh, A.; Zhang, J.; O'Campo, P. Pathways and trajectories linking housing instability and poor health among low-income women experiencing intimate partner violence (IPV): Toward a conceptual framework. Women Health 2015, 56, 208-225. [CrossRef] [PubMed] 
123. De Salles, D.; Maria, A.; de Lima, F.; Amélia, A.; Mingoti, S.A.; da Silva, C.D.Á.; de Rio, A.; Souza, A.; Amanda, C.; Freire, F.M.; et al. Mortality from Homicides in Slums in the City of Belo Horizonte, Brazil: An Evaluation of the Impact of a Re-Urbanization Project. Int. J. Environ. Res. Public Health 2019, 16, 154. [CrossRef] [PubMed]

124. Li, J.; Liu, Z. Housing stress and mental health of migrant populations in urban China. Cities 2018, 81, 172-179. [CrossRef]

125. Morris, A. 'I really have thought this can't go on': Housing tenure and health. Aust. Dream Hous. Exp. Older Aust. 2016, 147-178.

126. Lawder, R.; Walsh, D.; Kearns, A.; Livingston, M. Healthy Mixing? Investigating the Associations between Neighbourhood Housing Tenure Mix and Health Outcomes for Urban Residents. Urban. Stud. 2014, 51, 264-283. [CrossRef]

127. Arthurson, K. Mixed tenure communities and the effects on neighbourhood reputation and stigma: Residents' experiences from within. Cities 2013, 35, 432-438. [CrossRef]

128. Farre, A.; Rapley, T. The New Old (and Old New) Medical Model: Four Decades Navigating the Biomedical and Psychosocial Understandings of Health and Illness. Healthcare 2017, 5, 88. [CrossRef] [PubMed]

129. Lall, S.V.; Freire, M.; Yuen, B.; Rajack, R.; Helluin, J.-J. Urban. Land Markets: Improving Land Management for Successful Urbanization; Lall, S.V., Ed.; Springer: Dordrecht, The Netherlands, 2009.

130. Sjöstedt, M. The impact of secure land tenure on water access levels in sub-Saharan Africa: The case of Botswana and Zambia. Habitat Int. 2011, 35, 133-140. [CrossRef]

131. Uwayezu, E.; de Vries, W.T. Scoping land tenure security for the poor and low-income urban dwellers from a spatial justice lens. Habitat Int. 2019, 91, 102016. [CrossRef]

132. Fitzpatrick, S.; Watts, B. Competing visions: Security of tenure and the welfarisation of English social housing. Hous. Stud. 2017, 32, 1021-1038. [CrossRef] 